\title{
Analysis of quality characteristics of Ligularia fischeri cultivated in a greenhouse and an open field based on the harvest time
}

\author{
Ja-Yong $\mathrm{Cho}^{1}$, Su-Hwan $\mathrm{Kim}^{2}$, In-Kyung $\mathrm{Cho}^{3}$, Jae-Hee Jeong ${ }^{4}$, Jun-Ki Park ${ }^{4}$, \\ Do-Woo Gim ${ }^{4}$, Yong-Doo Kim ${ }^{4}$, Chang-Ki Huh ${ }^{4 *}$ \\ ${ }^{1}$ Department of Food Science and Biotechnology, Jeonnam State University, Damyang 57337, Korea \\ ${ }^{2}$ Imsil Cheese and Food Research Institute, Imsil 55918, Korea \\ ${ }^{3}$ Department of Food and Nutrition, Nambu University, Gwangju 62271, Korea \\ ${ }^{4}$ Department of Food Science and Technology, Sunchon National University, Suncheon 57922, Korea
}

\section{시설 및 노지재배 곰취의 수확시기에 따른 식품학적 특성 분석}

\author{
조자용 ${ }^{1} \cdot$ 김수환 $^{2} \cdot$ 조인경 ${ }^{3} \cdot$ 정재희 ${ }^{4} \cdot$ 박준기 $^{4} \cdot$ 김도우 ${ }^{4} \cdot$ 김용두 ${ }^{4} \cdot$ 허창기 $^{4 *}$ \\ 1전남도립대학교 식품생명과학과, ${ }^{2}$ 임실치즈\&식품연구소, ${ }^{3}$ 남부대학교 식품영양학과, ${ }^{4}$ 순천대학교 식품공학과
}

\begin{abstract}
This study was conducted to enhance the utilization of Ligularia fischeri as a food ingredient. The effects of the location of cultivation and the harvest time on the components were examined. The crude fats and proteins in greenhouse samples (GL) were $2 \%$ higher than those in open field samples (OL). The fat content was found to increase from $4.31 \%$ to $5.27 \%$ as the harvest time was delayed. The Na contents were more than two times higher in GL than in OL. Moreover, the amount of free sugars in leaves differed slightly according to the harvest time but decreased overall as the harvest time was delayed. The total polyphenols increased from 202.53 to 389.16 $\mathrm{mg} \%$ in OL and 293.57 to $439.40 \mathrm{mg} \%$ in GL as the harvest time was delayed. The levels of total flavonoids in OL and GL ranged from 105.58 to $202.79 \mathrm{mg} \%$ and 135.84 to $216.96 \mathrm{mg} \%$, respectively. These increased from 0.3 to 2 times upon delaying the harvest time. The samples were also analyzed for the presence of five catechin compounds, namely, (-)-epigallocatechin (EGC), (+)-catechin (CE), (-)-epigallocatechin gallate (EGCG), (-)-epicatechin gallate (ECG), and (-)-gallocatechin gallate (GCG). EGC and CE were detected in both OL and GL, while EGCG, ECG, and GCG were detected only in OL at low concentrations. The 4-O-caffeoylquinic acid content in GL was higher than that in OL, except in the early stages of harvesting.
\end{abstract}

Key words : Ligularia fischeri, cultivated method, catechin, 4-O-caffeoylquinic acid, food quality characteristics

\section{서 론}

산채류인 곰취(Gomchwi, Ligularia fischeri, LF)는 다년생 국화과 식물로서 중국, 한국, 일본 및 러시아 등의 극동아시 아에서 표고 $1,000 \mathrm{~m}$ 고지대(1)와 주로 개울과 경사지 주변

*Corresponding author. E-mail : hck1008@sunchon.ac.kr Phone : 82-61-750-3251, Fax : 82-61-750-3208

Received 5 October 2018; Revised 19 December 2018; Accepted 24 December 2018.

Copyright (c) The Korean Society of Food Preservation. All rights reserved.
의 습지고 그늘진 음지에서 잘 자란다 $(2,3)$. 우리나라에서 는 잎을 쌈이나 무침 등의 신선채소류(fresh vegetable)와 묵나물 등으로 식용하기 위하여 오랫동안 재배되었다 $(2,4,5)$. 곰취는 다 자라면 높이가 $1-2 \mathrm{~m}$ 정도이고, 꽃은 황색으로 7-9월에 피며, 열매는 수과로 길이가 6-10 mm 정도이다(6). 곰취 종자의 최적 발아온도는 $15^{\circ} \mathrm{C}$ 정도이고, 휴면기간은 $15-30$ 일 정도 소요되며, 발아율은 6.9-75.5\% 정도인데, 발아율을 높이기 위해서 저온 습윤처리와 $\mathrm{GA} 3$ $100 \mathrm{ppm}$ 침지처리, $\mathrm{BA}$ 처리 등을 종자처리하기도 한다 (2,7-9). 곰취는 광포화도가 낮은 음지식물이기 때문에 하계 에는 차광처리나 임간재배로 생산성을 높일 수 있고, 비교 
적 습윤한 지하부 환경이 생육에 적합한 산채류이다 (4,10-14). 곰취의 최적 생산시기는 4 월 중순에서 5 월말 정 도이며, 여름에는 병해충의 발생이 많아져서 가공용으로 출하시 이에 대한 대책이 필요하다 $(13,15)$.

최근에는 시설내 수경재배를 이용한 연중생산에 대한 연구가 이루어지고 있으며, 비교적 수익성이 높은 재배작 물이다 $(16,17)$. 최근에 곰취잎에서 생리활성을 높이는 caffeoylqunic acid와 CQA 유도체 등의 주요 폴리페놀 성분 들이 조사되어 곰취잎은 항산화작용이 높은 고부가가치 기능성 식품으로 여겨지고 있다(18-22). 또한, 곰취 뿌리 및 뿌리줄기는 호로칠(胡虜七)이라는 한약재로 사용되어 이기, 활혈, 지통, 지해, 거담 등의 효능으로 타박상, 요통, 가래, 기침, 객혈, 백일해 등을 치료한다(23). 곰취 뿌리에는 isopentenic acid, ligularone, liguloxide, liguloxidol, liguloxidol acetate 등의 유용성분이 함유되어 있다(6). 우리나라에서 곰취를 이용한 식품개발 연구를 보면 김치(24), 국수(25), 혼합양조간강(26), 설기떡(27), 인절미(28), 두부(29) 등이 있으며, 밀가루에 곰취분말을 첨가 시 곰취 분말량이 증가 할수록 대조군보다 높은 온도에서 호화가 개시되고(25), 일반성분과 당도는 첨가량이 증가할수록 유의적으로 증가 한다고 보고되어 있다(30). 이상과 같이 곰취는 영양성과 기능성이 뛰어나 식품의 소재로의 활용가치가 높으며 국내 에서 생산량과 생산면적이 점차 증가하고 있으며, 소비 역 시 증가하는 현황을 보이고 있다. 그러나 현재 곰취는 강원 도 및 고산지대를 중심으로 자생지에서 직접 채취하거나 노지에서 보통재배의 형태로 주로 생산되고 있는 실정이 다. 따라서 다양한 재배환경조절이 가능한 시설재배로 생 산성을 높이고 연중생산과 더불어 영양성과 기능성을 높일 수 있는 수경재배 등 첨단시설재배로의 전환이 필요하다. 곰취 시설재배는 자생지 수확 및 노지재배에 비해 생력적이 며, 소규모 면적에서 집약적 생산이 가능하고, 최적의 재배 환경조절로 곰취의 생산성 및 품질과 기능성을 향상시킬 수 있는 장점이 있다. 하지만 현재까지 곰취의 육묘, 온실 및 노지재배에 따른 기능성분과 영양성분 차이에 대한 연구 가 없다. 따라서 본 연구는 곰취의 노지와 하우스재배의 생육환경에 따른 기능성분과 영양성분 차이에 대한 연구를 통해 식품학적 및 가공적 특성에 대한 기초자료를 제공함으 로써 곰취의 시설재배를 통한 대량생산과 대중화를 위한 기반을 마련하고자 하였다.

\section{재료 및 방법}

\section{실험재료 및 시약}

본 실험에 사용된 곰취(Ligularia fischeri)는 노지(전남 화순군 북면 노기리 산 1)와 하우스(전남 담양군 고서면 성월리 349-1)에서 시기별로 채취한 시료를 사용하였다.
2017년 5월부터 2017년 6월까지 4회에 걸쳐 수확하였으며 동결 건조하여 분쇄한 다음 $-20^{\circ} \mathrm{C}$ 에서 보관하면서 시료로 사용 하였다. 본 실험에서 사용된 분석 및 추출, chromatography 사용 용매인 ethanol(HPLC용), acetonitrile (HPLC용) 및 methanol(HPLC용)은 J.T.Baker사(NJ, USA) 시약을 사용하였고, Folin-Ciocalteu's reagent는 Millipore사 (Darmstadt, Germany)의 것을 구입하여 사용하였다.

\section{일반성분 분석}

일반성분 분석은 $\mathrm{AOAC}$ 표준분석법(31)에 따라 실시하 였다. 수분은 $105^{\circ} \mathrm{C}$ 상압가열건조법, 회분은 $550^{\circ} \mathrm{C}$ 회화처 리, 조단백질의 함량은 Kjeldahl법, 조지방은 Soxhlet 추출법 으로 측정하였다.

\section{무기성분 분석}

무기성분은 건식분해법(32)으로 전처리하여 분석하였 다. 곰취 시료 $0.5 \mathrm{~g}$ 을 칭량하여 $550-600^{\circ} \mathrm{C}$ 로 회화시킨 후 증류수 $1 \mathrm{~mL}$ 와 질산 $0.5 \mathrm{~mL}$ 를 가하여 heating plate에서 백연현상이 일어날 때 까지 가열 시킨 다음 질산 $0.5 \mathrm{~mL}$ 를 가한 후 증류수 $100 \mathrm{~mL}$ 로 정용하여 검액으로 하였다. 각 무기성분의 정량은 원자흡광비색계(Perkin Elmer Analyst 300, Perkin Elmer Co., Norwalk, CT, USA)로 각 원소(K; $766.5 \mathrm{~nm}, \mathrm{Mg} ; 285.2 \mathrm{~nm}, \mathrm{Na} ; 589.0 \mathrm{~nm}, \mathrm{Ca} ; 422.7 \mathrm{~nm}, \mathrm{Fe}$; $248.3 \mathrm{~nm}, \mathrm{Zn} ; 214.9 \mathrm{~nm}$ )의 표준용액 농도를 1,3 및 $5 \mathrm{ppm}$ 으 로 조제하여 표준검량 곡선을 작성하여 분석하였다.

\section{유리당 분석}

유리당 성분은 Gancedo와 $\operatorname{Luh}(33)$ 의 방법에 따라 분석하 였다. 시료 $2 \mathrm{~g}$ 에 증류수를 가하고 homogenizer(OGAWA SEIKI Co., Ltd., Tokyo, Japan)로 마쇄하여 교반, 침출시킨 후 $10 \mathrm{~mL}$ 로 정용한 다음 원심분리 $(3,000 \times \mathrm{g}, 30 \mathrm{~min})$ 한 후 원심 분리한 상등액을 취하여 여과(Whatman No.2, Toyo Roshi Kaishi Ltd., Tokyo, Japan)하고 Sep-pak $\mathrm{C}_{18}$ 으로 정제 시킨 다음 $0.45 \mathrm{um}$ membrane filter (Millipore Co., Billerica, MA, USA)로 여과한 여액으로 HPLC를 이용하여 분석하였 다. Column은 Prevail Carbohydrate ES $5 \mu($ ID $4.6 \times 250 \mathrm{~mm}$, Grace Co., Deerfield, IL, USA)를 사용하였으며, mobile phase는 $75 \%$ acetonitrile, flow rate는 $0.6 \mathrm{~mL} / \mathrm{min}$, detector는 Evaporative Light Scattering Detector 2000ES(Alltech Co., Deerfield, IL, USA)를 사용하여 분석하였으며, 함량은 외부 표준법으로 나타내었다

\section{유기산 분석}

유기산 분석은 각각의 시료 $10 \mathrm{~g}$ 에 증류수를 가해 추출시 킨 후 $100 \mathrm{~mL}$ 로 정용한 다음 $3,000 \mathrm{rpm}$ 에서 30 분간 원심 분리 후 상징액을 취하여 여과(Whatman No.2, Toyo Roshi Kaishi Ltd.)하고, Sep-pak $\mathrm{C}_{18}$ 으로 정제시킨 다음 $0.45 \mu \mathrm{m}$ 
membrane filter(Millipore Co., Billerica, MA USA)로 여과한 여 액 HPLC(Waters M510, Waters Co., Milford, MA, USA) 로 분석하였고, column은 organic acid column(ID 4.6×250 $\mathrm{mm}$, Grace Co., Waukegan, IL, USA)를 사용하였으며, mobile phase는 $0.2 \mathrm{mM}$ potassium dihydrogen phosphate buffer $\mathrm{KH}_{2} \mathrm{PO}_{4}$, flow rate는 $1.0 \mathrm{~mL} / \mathrm{min}$, detector는 diode array detector(1100 Series, Agilent Co., Oceanside, CA, USA)를 사용하여 함량은 외부표준법으로 나타내었다.

\section{Total polyphenol 분석}

Total polyphenol 함량은 시료 $5 \mathrm{~g}$ 을 취해 $70 \%$ ethanol $50 \mathrm{~mL}$ 로 $80^{\circ} \mathrm{C}$ 에서 환류 추출한 후 Folin-Denis법(34)법에 따라 총 폴리페놀 함량을 정량하였다. 즉, 추출물 $1 \mathrm{~mL}$ 에 Folin시약 $1 \mathrm{~mL}$ 을 첨가하고 3분후에 $5 \% \mathrm{Na}_{2} \mathrm{CO}_{3} 2.5 \mathrm{~mL}$ 을 가하여 혼합하여 실온에서 1시간 반응시켰다. UV-spectrometer (Epoch. Biotek., VT 05404, Winooski, VT, USA)를 사용하여 $660 \mathrm{~nm}$ 에서 흡광도를 측정하였으며 표준물질 garlic acid를 기준으로 환산하여 나타내었다.

\section{Total flavonoid 분석}

Total flavonoids 함량측정은 Moreno 등(35)의 방법에 따 라 변형하여 측정하였다. 시료 $0.2 \mathrm{~mL}$ 에 $10 \%$ aluminiun nitrate $0.1 \mathrm{~mL}, 1 \mathrm{M}$ potassium acetate $0.1 \mathrm{~mL}, 80 \%$ ethanol $4.6 \mathrm{~mL}$ 를 가한 후 실온에서 40 분간 반응 시킨 후 UV-spectrometer(Epoch. Biotek., VT 05404)를 사용하여, $415 \mathrm{~nm}$ 에서 흡광도 측정하였다. 표준물질 quercetin을 기준 으로 환산하여 나타내었다.

\section{Catechins 분석}

시료용액의 제조는 곰취 $10 \mathrm{~g}$ 을 $200 \mathrm{~mL}$ 의 플라스크에 취하여 증류수는 $100 \mathrm{~mL}$ 를 가한 후 $80^{\circ} \mathrm{C}$ 의 열탕 속에서 10 분간 가온 추출하였다. 실온에서 냉각한 후 증류수를 가 하여 $100 \mathrm{~mL}$ 로 정용하고 여과지로 여과한 여과액 $50 \mathrm{~mL}$ 에 $50 \mathrm{~mL}$ 의 클로로포롬을 가해 카페인을 제거하였다. 카페인 을 제거한 추출액을 ethaylacetate $50 \mathrm{~mL}$ 를 가하여 catechin 류를 추출하여 감압 농축 후 다시 ethylacetate $5 \mathrm{~mL}$ 로 정용 하여 $0.45 \mu \mathrm{m}$ 의 membrane filter를 통과 시켜 정제한 후 HPLC를 이용하여 catechin 함량을 분석하였다 $(36,37)$. Column은 Capcell pak $\mathrm{C}_{18}$ column(250 mm L×4.6 mm I.D, Shiseido Co., Tokyo, Japan)를 사용하였고, mobile phase는 acetonitrile:ethyl acetate:0.1\% $\mathrm{H}_{3} \mathrm{PO}_{4}=12: 2: 86(\mathrm{v} / \mathrm{v} / \mathrm{v})$, flow rate는 $1.0 \mathrm{~mL} / \mathrm{min}$, detector는 Waters $2489 \mathrm{UV}$ detector 280 $\mathrm{nm}$ (Waters Co., Milford, MA, USA)를 사용하여 함량은 외 부표준법으로 나타내었다.

\section{4-O-Caffeoylquinic acid 분석}

4-O-Caffeoylquinic acid 분석은 Ganzon 등(38)의 방법으 로 분석하였다. 즉, 시료 $1 \mathrm{~g}$ 에 $50 \%$ methanol을 $10 \mathrm{~mL}$ 가한
후 초음파 세척기에서 30 분간 추출하였으며, 이 과정을 3 반 복하여 $50 \mathrm{~mL}$ 로 정용하여 시료 용액으로 사용하였다. 이 시료용액을 $0.45 \mu \mathrm{m}$ membrane filter(Millipore Co.,)로 여과 하여 HPLC를 이용하여 분석하였다. 분석조건은 Table 1과 같으며, 함량은 외부표준법으로 계산하였다.

\section{통계분석}

실험결과는 3회 반복 측정하여 SPSS 버전 program을 사용하였고, mean $\pm \mathrm{SD}$ 을 구하였으며 Duncan's multiple range test로 시료간의 유의차를 다중 비교법으로 분석하였다.

Table 1. HPLC condition for the analysis of 4-O-caffeoylquinic acid

\begin{tabular}{ccc}
\hline \multicolumn{1}{c}{ Item } & \multicolumn{2}{c}{ Condition } \\
\hline \multirow{2}{*}{ Instrument } & \multicolumn{3}{c}{$\begin{array}{c}\text { Waters Alliance e2695 } \\
\text { (Waters Co.) }\end{array}$} \\
\hline \multirow{2}{*}{ Detector } & \multicolumn{3}{c}{ Waters 2489 UV detector $280 \mathrm{~nm}$} \\
(Waters Co.)
\end{tabular}

\section{결과 및 고찰}

\section{일반성분 함량}

곰취의 생육환경 및 채취시기에 따른 일반성분 분석결과 는 Table 2 와 같다. 5 월 10 일에 채취한 노지재배 곰취의 일반성분 함량은 수분 $1.21 \%$, 조단백질 $15.65 \%$, 조지방 $4.62 \%$, 조회분 $14.25 \%$ 이며, 5 월 17 일에 채취한 노지재배 곰취는 수분 $1.42 \%$, 조단백질 $15.31 \%$, 조지방 $4.19 \%$, 조회 분 $14.63 \%, 6$ 월 2 일에 채취한 노지재배 곰취의 수분 함량은 $1.28 \%$, 조단백질 $15.98 \%$, 조지방 $4.37 \%$, 조회분 $14.76 \%$ 이 었으며, 6월 19일에 채취한 노지재배 곰취의 조수분 함량은 $1.18 \%$, 조단백질 $15.68 \%$, 조지방 $4.31 \%$, 조회분 $14.58 \%$ 로 
Table 2. Proximate composition of Ligularia fischeri according to growing place and harvest time

(unit: \%)

\begin{tabular}{|c|c|c|c|c|c|}
\hline Sample ${ }^{1)}$ & Harvest time & Moisture & Crude protein & Crude fat & Crude ash \\
\hline \multirow{4}{*}{$\mathrm{OL}$} & May $10^{\text {th }}$ & $1.21 \pm 0.42^{2)(e 3)}$ & $15.65 \pm 0.42^{d}$ & $4.62 \pm 0.34^{c}$ & $14.26 \pm 0.51^{f}$ \\
\hline & May $17^{\text {th }}$ & $1.42 \pm 0.11^{\mathrm{c}}$ & $15.31 \pm 0.27^{\mathrm{e}}$ & $4.19 \pm 0.24^{\mathrm{d}}$ & $14.36 \pm 0.50^{\mathrm{e}}$ \\
\hline & June $2^{\text {nd }}$ & $1.28 \pm 0.51^{\mathrm{e}}$ & $15.98 \pm 1.36^{\mathrm{c}}$ & $4.37 \pm 0.14^{\mathrm{d}}$ & $14.76 \pm 0.52^{b}$ \\
\hline & June $19^{\text {th }}$ & $1.18 \pm 0.23^{\mathrm{f}}$ & $15.68 \pm 0.21^{\mathrm{d}}$ & $4.31 \pm 0.05^{\mathrm{d}}$ & $14.58 \pm 0.41^{\mathrm{c}}$ \\
\hline \multirow{4}{*}{ GL } & May $10^{\text {th }}$ & $1.20 \pm 0.08^{\mathrm{f}}$ & $16.85 \pm 0.81^{\mathrm{a}}$ & $5.24 \pm 0.10^{\mathrm{ab}}$ & $14.47 \pm 0.23^{\mathrm{d}}$ \\
\hline & May $17^{\text {th }}$ & $1.52 \pm 0.12^{\mathrm{b}}$ & $16.47 \pm 1.05^{b}$ & $5.13 \pm 0.14^{b}$ & $14.82 \pm 0.57^{\mathrm{a}}$ \\
\hline & June $2^{\text {nd }}$ & $1.35 \pm 0.33^{\mathrm{d}}$ & $16.83 \pm 1.17^{\mathrm{a}}$ & $5.10 \pm 0.18^{b}$ & $14.35 \pm 0.88^{\mathrm{e}}$ \\
\hline & June $19^{\text {th }}$ & $1.71 \pm 0.19^{\mathrm{a}}$ & $15.97 \pm 2.33^{c}$ & $5.27 \pm 0.18^{\mathrm{a}}$ & $13.87 \pm 0.69^{\mathrm{g}}$ \\
\hline
\end{tabular}

${ }^{1)} \mathrm{OL}$, Ligularia fischeri grown at open field; GL, Ligularia fischeri grown at greenhouse.

${ }^{2)}$ All values are mean $\pm \mathrm{SD}$.

${ }^{3}$ Mean \pm SD with different superscripts within the same column are significantly different $(\mathrm{p}<0.05)$ by Duncan's multiple range test $(a>b>c>d>e>f>g>h)$.

노지재배 곰취의 채취시기별 일반성분 함량은 유의적인 차이가 나타나지 않았다. 하우스에서 재배한 곰취의 일반 성분 함량은 5 월 10 일에 채취한 곰취의 경우 수분 함량 $1.20 \%$, 조단백질 $16.85 \%$, 조지방 $5.24 \%$, 조회분 $14.47 \%$ 이 며, 5 월 17 일에 채취한 곰취의 수분 함량은 $1.52 \%$, 조단백질 $16.47 \%$, 조지방 $5.13 \%$, 조회분 $14.82 \%$ 함량이었다. 6 월 2일 에 채취한 하우스 곰취의 수분 함량은 $1.35 \%$, 조단백질 $16.83 \%$, 조지방 $5.10 \%$, 조회분 $14.35 \%$ 이었고, 6 월 19 일에 채취한 곰취의 수분 함량은 $1.71 \%$, 조단백질 $15.97 \%$, 조지 방 $5.27 \%$, 조회분 $13.87 \%$ 로 하우스 곰취 또한 채취시기별 일반성분 함량은 유의적인 차이를 보이지 않았다. 생육 환 경에 따른 일반성분 함량 차이를 보면 하우스재배 곰취가 노지재배 곰취의 수분 함량에 비해 약간 높게 나타났고, 조단백질 함량과 조지방 함량 또한 하우스재배 곰취가 노지 재배 곰취보다 약 $2 \%$ 정도 높게 나타났다. 조회분의 경우 생 육환경별 유의적인 차이를 보이지 않았다. 곰취에서 일
반 성분의 경우 노지재배와 하우스재배 등의 생육환경에 따라 다소 차이를 보인다고 여러 연구에서 보고되어 있다 (39). 이러한 함량 차이는 생육 환경이 하우스와 노지가 다른 환경을 갖고 있기 때문에 나타나는 결과로 판단된다.

\section{무기 성분 함량}

곰취의 생육환경 및 채취시기에 따른 무기성분 분석결과 는 Table 3 과 같다. 노지 곰취의 경우 5 월 10 일 채취 시료는 potassium $506.05 \mathrm{mg} \%$, calcium $213.75 \mathrm{mg} \%$, sodium 66.76 $\mathrm{mg} \%$, magnesium $161.61 \mathrm{mg} \%$, zinc $7.89 \mathrm{mg} \%$ 및 iron 0.37 $\mathrm{mg} \%$ 였고, 5월 17일 채취시료는 potassium $590.52 \mathrm{mg} \%$, calcium $225.98 \mathrm{mg} \%$, sodium $66.23 \mathrm{mg} \%$, magnesium 161.97 $\mathrm{mg} \%$, zinc $8.11 \mathrm{mg} \%$ 및 iron $0.38 \%$ 이었다. 6월 2일 채취시 료는 potassium $550.11 \mathrm{mg} \%$, calcium $238.71 \mathrm{mg} \%$, sodium $60.30 \mathrm{mg} \%$, magnesium $178.96 \mathrm{mg} \%$, zinc $7.23 \mathrm{mg} \%$ 및 iron $0.36 \%$ 로 나타났고, 6 월 19 일 채취시료는 potassium

Table 3. The contents of minerals in Ligularia fischeri according to growing place and harvest time

(unit: $\mathrm{mg} \%$ )

\begin{tabular}{|c|c|c|c|c|c|c|c|}
\hline \multirow{2}{*}{ Sample ${ }^{1)}$} & \multirow{2}{*}{ Harvest time } & \multicolumn{6}{|c|}{ Component } \\
\hline & & $\mathrm{K}$ & $\mathrm{Ca}$ & $\mathrm{Na}$ & $\mathrm{Mg}$ & $\mathrm{Zn}$ & $\mathrm{Fe}$ \\
\hline \multirow{4}{*}{$\mathrm{OL}$} & May $10^{\text {th }}$ & $506.05 \pm 76.95^{2 \mathrm{hb} 3}$ & $213.75 \pm 35.86^{c}$ & $66.76 \pm 10.80^{c}$ & $161.61 \pm 14.22^{d}$ & $7.89 \pm 1.34^{\mathrm{c}}$ & $0.37 \pm 0.01^{b}$ \\
\hline & May $17^{\text {th }}$ & $590.52 \pm 57.48^{\mathrm{f}}$ & $225.98 \pm 25.44^{\mathrm{bc}}$ & $66.23 \pm 6.26^{c}$ & $161.97 \pm 4.72^{d}$ & $8.11 \pm 0.08^{b c}$ & $0.38 \pm 0.01^{b}$ \\
\hline & June $2^{\text {nd }}$ & $550.11 \pm 46.41^{\mathrm{g}}$ & $238.71 \pm 26.21^{b}$ & $60.30 \pm 4.49^{\mathrm{cd}}$ & $178.96 \pm 25.67^{\mathrm{c}}$ & $7.23 \pm 0.14^{\mathrm{c}}$ & $0.36 \pm 0.04^{b}$ \\
\hline & June $19^{\text {th }}$ & $628.95 \pm 62.43^{c}$ & $208.89 \pm 31.72^{c}$ & $54.67 \pm 0.51^{d}$ & $160.83 \pm 10.47^{\mathrm{d}}$ & $7.32 \pm 0.21^{c}$ & $0.31 \pm 0.01^{\mathrm{c}}$ \\
\hline \multirow{4}{*}{ GL } & May $10^{\text {th }}$ & $598.86 \pm 30.60^{\mathrm{e}}$ & $287.71 \pm 17.84^{\mathrm{a}}$ & $131.60 \pm 2.28^{a}$ & $212.01 \pm 18.05^{\mathrm{a}}$ & $9.47 \pm 0.21^{\mathrm{a}}$ & $0.49 \pm 0.02^{\mathrm{a}}$ \\
\hline & May $17^{\text {th }}$ & $660.84 \pm 98.53^{b}$ & $290.33 \pm 28.12^{\mathrm{a}}$ & $131.71 \pm 7.79^{\mathrm{a}}$ & $209.71 \pm 29.15^{\mathrm{a}}$ & $8.31 \pm 1.13^{b}$ & $0.49 \pm 0.01^{\mathrm{a}}$ \\
\hline & June $2^{\text {nd }}$ & $611.28 \pm 73.45^{\mathrm{d}}$ & $292.03 \pm 13.16^{\mathrm{a}}$ & $121.34 \pm 5.49^{b}$ & $198.51 \pm 16.72^{b}$ & $8.57 \pm 0.63^{b}$ & $0.46 \pm 0.00^{\mathrm{a}}$ \\
\hline & June $19^{\text {th }}$ & $662.47 \pm 37.19^{\mathrm{a}}$ & $289.84 \pm 16.24^{\mathrm{a}}$ & $119.94 \pm 6.51^{\mathrm{b}}$ & $202.25 \pm 9.99^{\mathrm{ab}}$ & $8.45 \pm 1.41^{\mathrm{b}}$ & $0.51 \pm 0.02^{\mathrm{a}}$ \\
\hline
\end{tabular}

${ }^{1)} \mathrm{OL}$, Ligularia fischeri grown at open field; GL, Ligularia fischeri grown at greenhouse.

${ }^{2)}$ All values are mean $\pm \mathrm{SD}(\mathrm{n}=3)$.

${ }^{3}$ Mean \pm SD with different superscripts within the same column are significantly different $(\mathrm{p}<0.05)$ by Duncan's multiple range test $(a>b>c>d>e>f>g>h>i)$. 
$628.95 \mathrm{mg} \%$, calcium $208.89 \mathrm{mg} \%$, sodium $54.67 \mathrm{mg} \%$, magnesium $160.83 \mathrm{mg} \%$, zinc $7.32 \mathrm{mg} \%$ 및 iron $0.31 \mathrm{mg} \%$ 로 나타났다. 검출된 무기성분 중 주요 무기성분은 potassium 과 calcium으로 확인이 되었다. 채취시기에 따른 무기 성분 함량 변화를 보면 potassium의 함량은 채취시기가 경과할수 록 높아지는 경향을 보였고, sodium 함량은 감소하는 경향 을 보였으며, 그 외 성분은 유의적인 차이를 보이지 않았다. 하우스재배 곰취의 무기성분 함량은 5 월 10 일 채취시료는 potassium $598.86 \mathrm{mg} \%$, calcium $287.71 \mathrm{mg} \%$, sodium 131.60 $\mathrm{mg} \%$, magnesium $212.01 \mathrm{mg} \%$, zinc $9.47 \mathrm{mg} \%$ 및 iron 0.49 $\mathrm{mg} \%$ 였고, 5월 17일 채취시료는 potassium $660.84 \mathrm{mg} \%$, calcium $290.33 \mathrm{mg} \%$, sodium $131.71 \mathrm{mg} \%$, magnesium $209.71 \mathrm{mg} \%$, zinc $8.31 \mathrm{mg} \%$ 및 iron $0.49 \mathrm{mg} \%$ 이었다. 6월 2일 채취시료는 potassium $611.28 \mathrm{mg} \%$, calcium 292.03 $\mathrm{mg} \%$, sodium $121.34 \mathrm{mg} \%$, magnesium $198.51 \mathrm{mg} \%$, zinc $8.57 \mathrm{mg} \%$ 및 iron $0.46 \mathrm{mg} \%$ 였고, 6월 19일 채취시료는 potassium $662.47 \mathrm{mg} \%$, calcium $289.84 \mathrm{mg} \%$, sodium 119.94 $\mathrm{mg} \%$, magnesium $202.25 \mathrm{mg} \%$, zinc $8.45 \mathrm{mg} \%$, iron 0.51 $\mathrm{mg} \%$ 로 나타났다. 하우스재배 곰취 또한 주요 무기성분은 potassium과 calcium으로 확인이 되었고, 노지재배 곰취와 비교해 potassium, calcium, sodium, magnesium, zinc 및 iron 성분 모두 하우스재배 곰취가 높게 나타났다. 특히 sodium 함량은 하우스재배 곰취가 노지재배 곰취에 비해 2배 이상 으로 나타났다. Hwang 등(40)이 조사한 약초중의 무기성분 함량 중 국화의 경우 potassium이 가장 많은 함량을 나타내 었으며, 다음으로 calcium이 높게 함유되어 있는 것으로 보고하여 본 연구와 같은 경향을 나타내었다.

\section{유리당 함량}

식물은 광합성을 통해 포도당을 생성하고, 생성된 포도 당을 녹말 및 셀롤로오스 등의 형태로 저장하며, 우리 인간 에게 매우 중요한 에너지 공급원으로 활용된다(41). 이러한
이유로 곰취의 생육환경 및 채취시기에 따른 유리당 함량을 측정 결과는 Table 4와 같다. 곰취에서 검출된 유리당은 fructose, glucose 및 sucrose 3종의 유리당이 검출되었으며, 그 중 glucose의 함량이 fructose와 sucrose 함량에 비해 큰 차이를 보이며 높게 나타났다. 이는 앞서 설명한 바와 같이 광합성을 통해 1 차 포도당을 생성하는 과정에서 나타난 결과라고 판단된다. 채취 시기별 총 유리당 함량을 보면 최초 채취 시기인 5 월 10 일 곰취의 채취 시기가 늦은 시료구 에 비해 35-90배 이상 높은 함량을 보였다. 특히 곰취의 주요 유리당으로 확인된 glucose의 함량 차이가 크게 나타 났다. 이러한 결과는 생육 초기에 광합성 작용이 활발히 일어나 glucose가 많이 생성되어 나타난 결과로 판단된다. 생육 환경에 따른 총 유리당 함량은 5 월 10 일 채취 시료구의 경우 노지재배 곰취가 $3,513.87 \mathrm{mg} \%$ 로 하우스재배 곰취의 $2,243.73 \mathrm{mg} \%$ 에 비해 높은 함량을 보였다. 이러한 결과는 앞서 일반성분을 분석한 결과와 연계해서 볼 때 하우스재배 곰취가 수분 함량은 차이를 보이지 않았지만 조단백질, 조 지방 및 조회분 함량은 노지재배 곰취에 비해 모두 약간씩 높았기 때문에 가용성 무기 질소물의 함량이 낮아져 나타난 결과로 판단된다. 6월 2일 이후 채취된 시료구부터는 노지 재배 곰취와 하우스재배 곰취의 총 유리당 함량 차이가 크지 않았다. $\operatorname{Kim}(11)$ 은 곰취의 생육환경에 따른 광합성율 을 조사한 결과 광도가 증가함에 따라 광합성율이 높아짐을 보고하였으며, 차광처리에 의한 곰취 또한 같은 경향을 나 타내었음을 보고였다. 본 연구의 하우스재배 곰취의 경우 차광처리에 의한 영향으로 노지재배 곰취보다 낮은 광합성 율을 나타낼 것으로 사료되어 노지재배 곰취보다 낮은 유리 당 함량을 나타낸 것으로 판단된다.

\section{유기산 함량}

곰취의 생육환경 및 채취시기에 따른 유기산 함량을 측 정한 결과는 Table 5와 같으며, citric acid를 비롯한 5종의

Table 4. The content of free sugars in Ligularia fischeri according to growing place and harvest time

(unit: $\mathrm{mg} \%$ )

\begin{tabular}{|c|c|c|c|c|c|}
\hline Sample ${ }^{1)}$ & Harvest time & Fructose & Glucose & Sucrose & Total free sugars \\
\hline \multirow{4}{*}{$\mathrm{OL}$} & May $10^{\text {th }}$ & $20.38 \pm 5.70^{22 b 3)}$ & $3,395.09 \pm 924.85^{\mathrm{a}}$ & $98.40 \pm 6.01^{\mathrm{a}}$ & $3,513.87$ \\
\hline & May $17^{\text {th }}$ & $7.56 \pm 1.27^{g}$ & $901.37 \pm 36.23^{c}$ & $46.99 \pm 0.27^{c}$ & 955.92 \\
\hline & June $2^{\text {nd }}$ & $11.28 \pm 0.15^{\mathrm{f}}$ & $557.40 \pm 34.69^{\mathrm{d}}$ & $21.61 \pm 0.40^{\mathrm{d}}$ & 590.29 \\
\hline & June $19^{\text {th }}$ & $11.12 \pm 0.21^{\mathrm{f}}$ & $375.00 \pm 6.60^{e}$ & $22.45 \pm 0.14^{\mathrm{d}}$ & 408.57 \\
\hline \multirow{4}{*}{ GL } & May $10^{\text {th }}$ & $188.72 \pm 0.85^{\mathrm{a}}$ & $1,968.80 \pm 119.17^{b}$ & $86.21 \pm 0.64^{\mathrm{ab}}$ & $2,243.73$ \\
\hline & May $17^{\text {th }}$ & $13.72 \pm 0.14^{\mathrm{e}}$ & $286.32 \pm 22.27^{\mathrm{f}}$ & $95.56 \pm 0.96^{\mathrm{a}}$ & 395.60 \\
\hline & June $2^{\text {nd }}$ & $14.89 \pm 1.08^{\mathrm{d}}$ & $389.16 \pm 0.40^{\mathrm{e}}$ & $70.27 \pm 0.82^{b}$ & 474.32 \\
\hline & June $19^{\text {th }}$ & $15.61 \pm 0.08^{\mathrm{c}}$ & $360.33 \pm 12.83^{\mathrm{e}}$ & $29.82 \pm 0.57^{\mathrm{d}}$ & 405.76 \\
\hline
\end{tabular}

${ }^{1)} \mathrm{OL}$, Ligularia fischeri grown at open field; GL, Ligularia fischeri grown at greenhouse.

${ }^{2)}$ All values are mean \pm SD $(n=3)$.

${ }^{33}$ Mean \pm SD with different superscripts within the same column are significantly different $(\mathrm{p}<0.05)$ by Duncan's multiple range test $(\mathrm{a}>\mathrm{b}>\mathrm{c}>\mathrm{d}>\mathrm{e}>\mathrm{f}>\mathrm{g})$. 
Table 5. The content of organic acid in Ligularia fischeri according to growing place and harvest time

(unit: $\mathrm{mg} \%$ )

\begin{tabular}{|c|c|c|c|c|c|c|c|}
\hline Sample ${ }^{1)}$ & Harvest time & Oxalic acid & Tartaric acid & Acetic acid & Citric acid & Succinic acid & Total organic acids \\
\hline \multirow{4}{*}{$\mathrm{OL}$} & May $10^{\text {th }}$ & $191.70 \pm 3.22^{2) b 3)}$ & $70.51 \pm 0.87^{d}$ & $13.83 \pm 0.53^{d}$ & $283.49 \pm 10.30^{b}$ & $795.65 \pm 59.31^{\mathrm{b}}$ & $1,365.18$ \\
\hline & May $17^{\text {th }}$ & $185.85 \pm 4.63^{\mathrm{bc}}$ & $69.86 \pm 2.79^{\mathrm{d}}$ & $16.18 \pm 1.21^{\mathrm{d}}$ & $375.40 \pm 27.41^{\mathrm{a}}$ & $775.74 \pm 16.71^{\text {bc }}$ & $1,440.03$ \\
\hline & June $2^{\text {nd }}$ & $191.08 \pm 1.92^{\mathrm{b}}$ & $103.42 \pm 8.63^{c}$ & $7.21 \pm 1.27^{e}$ & $346.37 \pm 21.03^{\mathrm{a}}$ & $847.43 \pm 25.62^{\mathrm{a}}$ & $1,497.51$ \\
\hline & June $19^{\text {th }}$ & $188.55 \pm 6.64^{\mathrm{bc}}$ & $103.36 \pm 15.37^{\mathrm{c}}$ & $7.32 \pm 0.48^{\mathrm{e}}$ & $330.62 \pm 16.08^{\mathrm{ab}}$ & $768.21 \pm 38.28^{\mathrm{c}}$ & $1,417.06$ \\
\hline \multirow{4}{*}{ GL } & May $10^{\text {th }}$ & $225.64 \pm 11.02^{\mathrm{a}}$ & $145.47 \pm 8.89^{\mathrm{ab}}$ & $32.01 \pm 6.91^{\mathrm{c}}$ & $31.20 \pm 8.20^{\mathrm{d}}$ & $92.25 \pm 9.72^{e}$ & 536.57 \\
\hline & May $17^{\text {th }}$ & $199.48 \pm 2.60^{b}$ & $147.42 \pm 4.19^{\mathrm{ab}}$ & $43.74 \pm 3.78^{b}$ & $17.86 \pm 1.07^{\mathrm{e}}$ & $98.69 \pm 4.64^{\mathrm{de}}$ & 524.19 \\
\hline & June $2^{\text {nd }}$ & $198.47 \pm 3.22^{b}$ & $168.30 \pm 9.58^{\mathrm{a}}$ & $42.06 \pm 5.57^{\mathrm{b}}$ & $32.93 \pm 1.05^{\mathrm{d}}$ & $85.02 \pm 6.19^{e}$ & 528.78 \\
\hline & June $19^{\text {th }}$ & $216.86 \pm 10.63^{\mathrm{a}}$ & $132.82 \pm 11.53^{b}$ & $53.06 \pm 1.34^{\mathrm{a}}$ & $30.92 \pm 2.59^{d}$ & $85.60 \pm 5.44^{e}$ & 538.26 \\
\hline
\end{tabular}

${ }^{1)} \mathrm{OL}$, Ligularia fischeri grown at open field; GL, Ligularia fischeri grown at greenhouse.

${ }^{2)}$ All values are mean $\pm \mathrm{SD}(\mathrm{n}=3)$.

${ }^{33}$ Mean \pm SD with different superscripts within the same column are significantly different $(p<0.05)$ by Duncan's multiple range test $(a>b>c>d>e)$.

유기산이 함유되어 있었다. 검출된 유기산의 종류별 조성 을 보면 노지재배 곰취의 경우 succinic acid와 citric acid 주요 유기산으로 확인 되었고, 하우스재배 곰취의 경우 oxalic acid와 tartaric acid가 주요 유기산으로 확인되어 생육 환경에 따른 주요 유기산이 차이가 있었다. 유기산의 조성 이 본 연구 결과와 같이 현저히 차이가 나는 이유를 설명하 기 위해선 여러 가지 요인 분석을 통해 결과를 분석해야 할 것으로 판단된다. 그러한 요인으로는 품종의 차이, 재배 환경에 따른 대사 과정의 차이, 시비 및 토양의 질 차이 등의 여러 요인이 있을 것으로 판단되며, 향후 이러한 요인 을 파악하는데 추가 연구가 필요할 것으로 판단된다. 채취 시기별 곰취의 유기산 함량 변화는 oxalic acid, tartaric acid, succinic acid, acetic acid, citric acid 모두 유의적 차이를 보이지 않았다. 본 연구를 통해 곰취에는 여러 종류의 유기 산이 다량 함유 되어 있었으며 이러한 유기산 함량이 여러 가지 다양한 맛에 관여할 것으로 사료 된다.

\section{Total polyphenol과 total flavonoid 함량}

Polyphenol 화합물은 대표적인 항산화 물질로서 식물계 에 다수 존재하며, 항산화 및 항암 등 다양한 생리활성 기능 을 가지게 된다(42). 곰취의 생육환경 및 채취시기에 따른 total polyphenol 함량 측정 결과는 Table 6과 같다. 채취 시기에 따른 total polyphenol 함량은 노지재배의 경우 5 월 10 일에 채취한 곰취는 $202.53 \mathrm{mg} \%, 5$ 월 17 일 $340.96 \mathrm{mg} \%$, 6월 2일 $332.17 \mathrm{mg} \%$, 6월 19 일 $389.16 \mathrm{mg} \%$ 로 채취시기가 지날수록 높아지는 경향을 보였으며, 하우스재배 곰취 또 한 5월 10 일 $293.57 \mathrm{mg} \%, 5$ 월 17 일 $384.44 \mathrm{mg} \%, 6$ 월 2일 $407.97 \mathrm{mg} \%$, 6월 19일에 $439.40 \mathrm{mg} \%$ 로 채취시기가 지날수 록 total polyphenol 함량이 높아졌다. 다양한 기능성을 갖는 total polyphenol 함량을 분석한 본 연구의 결과는 곰취의 채취 시기를 결정할 때 중요한 자료로 사용될 수 있는 결과 로 판단된다. 생육 환경에 따른 total polyphenol 함량은 하우
Table 6. The content of total polyphenols and total flavonoids in Ligularia fischeri according to growing place and harvest time

(unit: $\mathrm{mg} \%$ )

\begin{tabular}{cccc}
\hline Sample $^{\text {1) }}$ & Harvest time & Total polyphenol & Total flavonoids \\
\hline \multirow{3}{*}{ OL } & May $10^{\text {th }}$ & $202.53 \pm 3.92^{2) e 3)}$ & $105.58 \pm 6.86^{\mathrm{d}}$ \\
& May $17^{\text {th }}$ & $340.96 \pm 3.45^{\mathrm{c}}$ & $168.36 \pm 0.72^{\mathrm{b}}$ \\
& June $2^{\text {nd }}$ & $332.17 \pm 4.14^{\text {cd }}$ & $194.07 \pm 4.06^{\mathrm{a}}$ \\
& June $19^{\text {th }}$ & $389.16 \pm 3.43^{\mathrm{c}}$ & $202.79 \pm 2.61^{\mathrm{a}}$ \\
\hline \multirow{3}{*}{ GL } & May $10^{\text {th }}$ & $293.57 \pm 2.27^{\mathrm{d}}$ & $135.84 \pm 0.13^{\mathrm{c}}$ \\
& May $17^{\text {th }}$ & $384.44 \pm 1.76^{\mathrm{c}}$ & $147.77 \pm 3.45^{\mathrm{c}}$ \\
& June $2^{\text {nd }}$ & $407.97 \pm 4.80^{\mathrm{b}}$ & $166.43 \pm 0.60^{\mathrm{b}}$ \\
& June $19^{\text {th }}$ & $439.40 \pm 3.32^{\mathrm{a}}$ & $216.96 \pm 2.60^{\mathrm{a}}$ \\
\hline
\end{tabular}

1)OL, Ligularia fischeri grown at open field; GL, Ligularia fischeri grown at greenhouse. ${ }^{2)}$ All values are mean \pm SD $(n=3)$.

${ }^{3} \mathrm{Mean} \pm \mathrm{SD}$ with different superscripts within the same column are significantly different $(p<0.05)$ by Duncan's multiple range test $(a>b>c>d>e)$.

스재배 곰취가 동일한 채취일 기준으로 대부분의 시료구에 서 높은 함량을 보였다. 식물에 널리 분포되어 있는 flavonoid는 polyphenol에 속하는 노란색 계열의 물질로 여 러 생리활성 기능을 가진 물질이다(43). 곰취의 생육환경 및 채취시기에 따른 total flavonoid 함량 측정 결과는 Table 6과 같다. 채취시기별 노지재배 곰취의 total flavonoid 함량 은 5월 10 일에 채취한 곰취는 $105.58 \mathrm{mg} \%$, 5월 17 일 168.36 $\mathrm{mg} \%$, 6월 2일 $194.07 \mathrm{mg} \%$, 6월 19일에 채취한 곰취는 $202.79 \mathrm{mg} \%$ 로 수확시기가 늦어질수록 함량이 높아지는 경향을 보였다. 하우스재배 곰취의 total flavonoid 함량 또 한 5 월 10 일에 채취한 곰취 $135.84 \mathrm{mg} \%, 5$ 월 17 일 147.77 $\mathrm{mg} \%$, 6월 2일 $166.43 \mathrm{mg} \%$, 6월 19일 $216.96 \mathrm{mg} \%$ 로 수확시 기가 늦어질수록 함량이 높아졌다. Total polyphenol 화합물 과 total flavonoid 화합물은 앞서 설명 한 바와 같이 밀접한 관련이 있는 화합물이며 기능성 물질로 알려져 있다. 본 
연구에서의 채취 시기별 함량 변화를 측정한 결과 두 화합 물의 함량 변화가 유의성 있게 나타난 결과 또한 밀접한 관련이 있을 것으로 판단된다. 생육 환경별 곰취의 total polypheonl 함량은 하우스재배 곰취 함량이 노지재배 곰취 에 비해 높은 함량을 보인 반면 total flavonoids 함량의 경우 5월 17일, 6월 2일 노지재배에서 채취한 곰취 함량이 높게 나타났다. 이는 Suh 등(44)이 연구한 곰취의 수확시기별 생리활성 비교 연구 결과 수확시기에 따른 곰취의 total polyphenol과 total flavonoid 함량이 수확시기가 늦어짐에 따라 증가하는 경향을 나타내었으며, total polyphenol이 total flavonoid보다 높은 함량을 나타내는 경향을 나타내어 본 연구와 일치하는 경향을 나타내었다. Chon(45)의 차광 처리에 따른 시설하우스재배 고들빼기의 생육 및 생리활성 변화 결과 차광정도가 클수록 높은 total polyphenol과 total flavonoid 함량을 보였으며, 본 연구에서 차광처리 재배한 하우스 곰취가 노지재배의 곰취보다 높은 함량을 보여 같은 경향을 나타냈다. 식물의 생리활성물질은 생육환경 스트레 스에 대한 식물의 방어기작 중 하나인 것으로 알려져 있어 (46), 재배환경에 따른 결과로 판단된다. 따라서 채취 시기 결정과 생육 환경을 선택할 때 total polyphenol 함량과 total flavonoid 함량을 분석한 본 자료는 유용한 자료가 될 것이 다.

\section{Catechin 함량}

생육환경 및 채취시기에 따른 catechin 함량을 분석한 결과는 아래 Fig. 1과 같다. 5종의 catechin 중 (-)epigallocatechin (EGC)과 (+)catechin(CE)이 주로 검출되었으며, (-)epigallo catechin gallate(EGCG), (-)epicatechin gallate(ECG) 및 (-)gallocatechin gallate(GCG)는 미량 검출 되었거나 검출되 지 않았다. 하우스재배 곰취의 경우 5 월 10 일 채취시료는 $\mathrm{CE}$ 함량이 $82.80 \mathrm{mg} \%$ 로 $\mathrm{EGC}$ 함량 $53.53 \mathrm{mg} \%$ 보다 높았으 나 채취시기가 늦어짐에 따라 더 낮거나 비슷한 수준을 나타내었다. 노지재배의 경우 5 월 10 일 채취시료의 $\mathrm{EGC}$ 함량이 $34.96 \mathrm{mg} \%$ 로 CE 함량 $16.20 \mathrm{mg} \%$ 보다 높았으나 채취시기가 늦어짐에 따라 $\mathrm{CE}$ 의 함량이 급격하게 증가하 여 $\mathrm{EGC}$ 보다 높은 함량을 나타내었다. 따라서 하우스재배 의 경우 5 월 10 일 채취시료가 노지재배의 경우 6 월 19 일 채취시료가 가장 높은 catechin 함량을 나타내었다. 생육 환경에 따른 catechin 함량은 5 월 10 일과 6 월 2 일에 수확한 곰취는 하우스 재배 환경에서 높은 catechin 함량을 보였으 나, 5월 17일과 6월 19일 채취시료는 하우스 재배 시료 보다 노지 재배 시료가 높은 catechin 함량을 나타내었다. Xiong 등(47)은 Camellia sinensis L.에서 카테킨 수준과 카 테킨 생합성에 관한 변화를 조사한 결과 잎이 성숙함에 따라 카테킨의 함량이 증가함을 나타내어 본 연구의 노지배 재 곰취와 일치하는 경향을 나타내었으나, 하우스재배의 경우 5 월 10 일 채취가 높은 가장 높은 함량을 낸 후 5 월
17 일 채취 시료에서 급격한 감소를 나타내었으며, 이후 완 만한 증가를 나타내어 노지재배 시료와 일치하는 경향을 나타내었다. 이는 시설재배의 장점인 생육속도조절에 의한 결과로 판단되며, 최적 생산시기가 4월 중순-5월말로 알려 진 곰취가 시설재배로 다양한 시기에 생산 될 수 있을 것으 로 판단된다.

\section{4-O-Caffeoylquinic acid 함량}

근래에 들어 국내에서 자생하는 산채류에 함유되어 있는 caffeoylquinic acid 유도체들에 관한 연구가 증가하고 있으 며 특히 국화과 산채류에는 caffoylquinic acid 유도체들이 풍부하게 함유되어 있으며 항산화, 간보호, 면역증진, 항균, 항바이러스 등 다양한 생리활성이 있음이 밝혀져 있다(48). 곰취의 생육환경과 채취시기에 따른 표준물질 4-O -caffeoylquinic acid 함량 측정결과는 Fig. 2와 같다. 생육환 경에 따른 4-O-caffeoylquinic acid함량은 재배초기를 제외 한 모든 시료구에서 노지의 생육환경 보다 하우스 생육환경 이 높은 함량을 나타내었다. 채취시기에 따른 함량은 6월
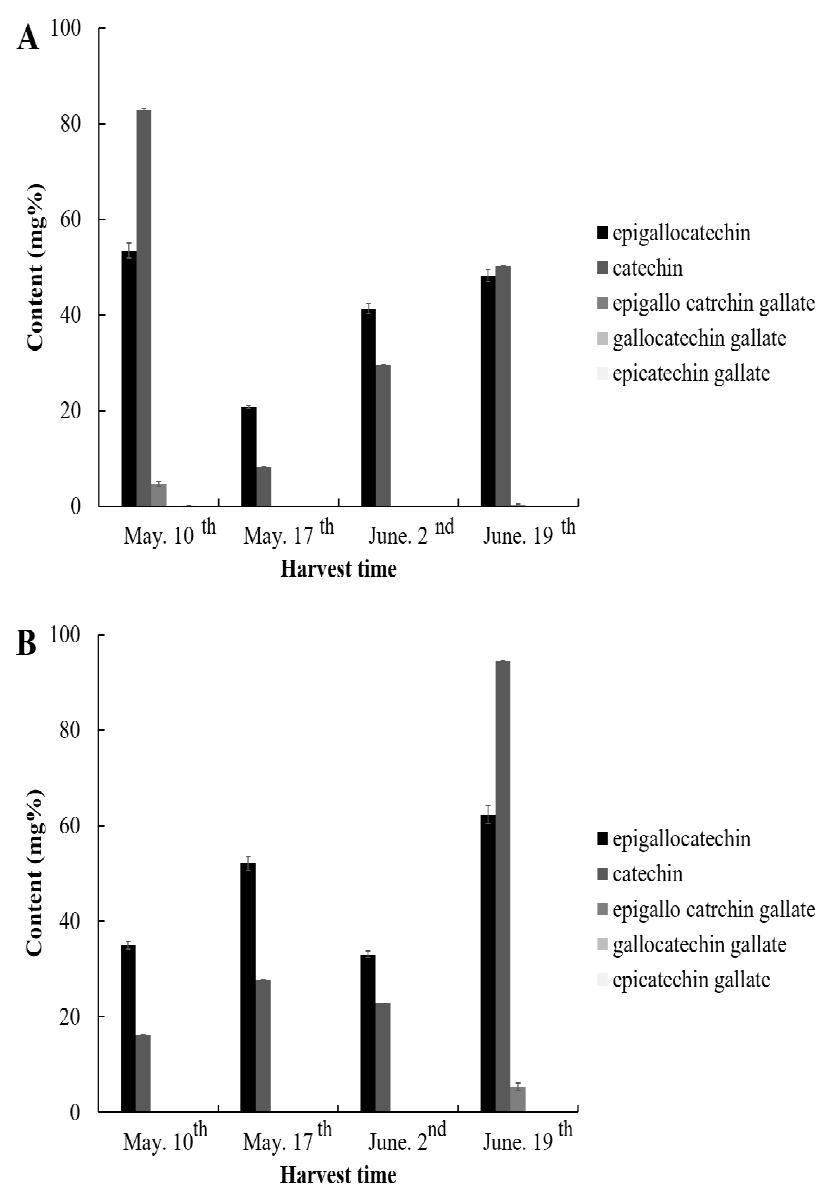

Fig. 1. The content of catechins in Ligularia fischeri according to growing place and harvest time.

A, Ligularia fischeri grown at greenhouse; B, Ligularia fischeri grown at open field. All values are mean $\pm S D$. 
2 일 채취 시료구가 노지재배와 하우스재배 모두 다른 시료 구에 비해 높게 나타났다. 5월 10 일 노지재배 곰취가 하우스 재배 곰취보다 높은 함량을 나타내었으나, 이후 5월 17 일, 6월 2일 그리고 6월 19일 채취 시료구는 노지재배 보다 하우스재배 시료구에서 높은 함량을 나타내었다. Ganzon 등(38)은 뽕나무(Morus alba L.) 잎의 채취시기에 따른 4-O -caffeoylquinic acid의 함량을 분석한 결과 총 채취 12 개월 중 채취 7개월째 급격한 증가를 나타내었으며, 이후 감소하 는 경향을 나타내어 본 연구와 유사한 경향을 나타내었다.

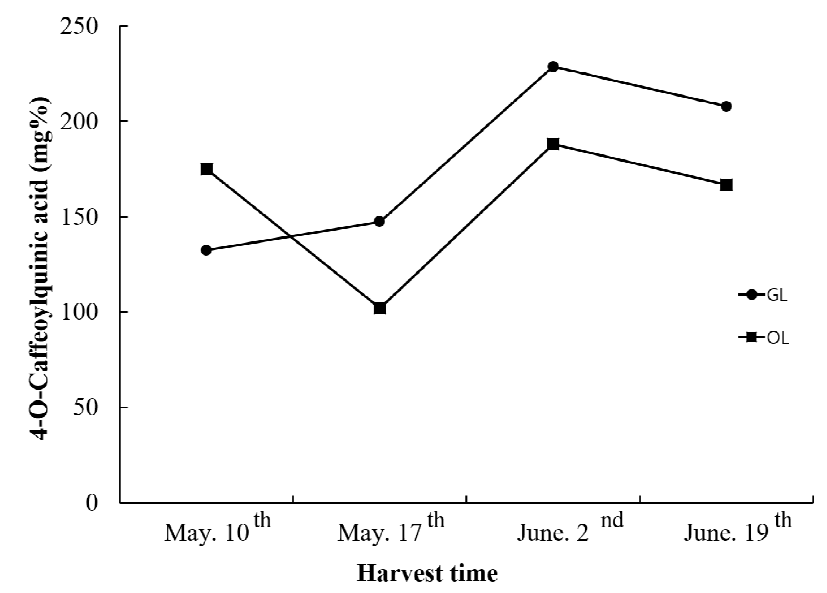

Fig. 2. The content of 4-O-caffeoylquinic acid in Ligularia fischeri according to growing place and harvest time.

GL, Ligularia fischeri grown at greenhouse; OL, Ligularia fischeri grown at open field.

\section{요 약}

본 연구는 곰취의 노지와 하우스재배의 생육환경에 따른 식품학적 특성과 가공적 특성의 기초 자료 제공을 목적으로 수행하였다. 생육환경에 따른 곰취의 조단백질 함량과 조 지방 함량은 하우스재배 곰취가 노지재배 곰취 보다 약 $2 \%$ 정도 높게 나타났다. 무기성분에서 $\mathrm{Na}$ 함량은 하우스재 배 곰취가 노지재배 곰취에 비해 2 배 이상 높게 나타났다. 곰취의 주요 유리당은 곰취의 채취시기에 따라 각 차이는 있었으나, 전체적으로 노지재배에 비하여 하우스재배 곰취 에서 감소하는 경향을 나타내었다. 유리당의 함량은 glucose $>$ sucrose $>$ fructose 순으로 나타났다. 주요 유기산 은 노지재배 곰취의 경우 succinic acid와 citric acid 등의 주요 유기산으로 확인되었고, 하우스재배 곰취의 경우 oxalic acid와 tartaric acid가 주요 유기산으로 확인되어 생육 환경에 따른 주요 유기산이 차이가 있었다. 곰취의 총 폴리 페놀 함량 변화를 보면 전체적으로 채취시기의 경과에 따라 증가하는 경향을 보였는데, 노지재배의 경우 202.53-389.16 $\mathrm{mg} \%$, 하우스재배의 경우 293.57-439.40 mg\% 순으로 수확 시기가 늦어질수록 약 1.5-2배 정도 증가하는 것으로 나타
났다. 총 플라보노이드 함량 변화는 노지재배의 경우 105.58-202.79 mg\%, 하우스재배의 경우 135.84-216.96 $\mathrm{mg} \%$ 순으로 수확시기가 늦어질수록 0.3-2배 정도 증가하 는 것으로 나타났다. 곰취의 생육환경에 따른 카테킨 함량 변화는 노지재배와 하우스재배에서 5 종의 catechin 중 (-)epigallocatechin(EGC)과 (+)catechin(CE)가 주로 검출되 었으며, (-)epigallo catechin gallate(EGCG), (-)epicatechin gallate(ECG) 및 (-)gallocatechin gallate(GCG)는 노지재배 곰취에서 미량 검출 되었다. 생육환경에 따른 4-O -caffeoylquinic acid 함량은 재배초기를 제외한 모든 시료구 에서 노지재배보다 하우스재배에서 높은 함량을 나타내 었다.

\section{감사의 글}

이 논문은 2018년 순천대학교 학술연구비 피로 연구되었 습니다. 이에 감사드립니다.

\section{References}

1. Ahn SY (2014) Studies on botanical characteristics and functional materials of Korean native plant resources in Gangwon Baekdudaegan. Ph D Thesis, Kangwon National University, Korea, p 35

2. Choi EM (2007) Ligularia fischeri leaf extract prevents the oxidative stress in DBA/1J mice with type II collagen-induced arthritis. J Appl Toxicol, 27, 176-182

3. Xie WD, Weng CW, Li X, Row KH (2010) Eremophilane sesquiterpenoids from Ligularia fischeri. Helv Chim Acta, 93, 1983-1989

4. Kwon KW, Kim GN, Cho MS (2009) Physiological responses of the three wild vegetables under different shading treatment. J Korean For Soc, 98, 106-114

5. An SJ, Park HS, Kim GH (2014) Evaluation of the antioxidant activity of cooked Gomchwi (Ligularia fischeri) using the myoglobin methods. Prev Nutr Food Sci, 19, 34-39

6. Bae KH (2000) The medical plants of Korea. Gyohaksa, Seoul, Korea, p 510

7. Yoo KO, Ahn SD, Chun IJ, Hong JK, Yoo CY, Kim JH, Kim SC, Lim HT (1996) Comparative studies of the five edible mountain vegetables by DNA marker fingerprinting. Korean J Plant Res, 9, 305-310

8. Lee KC, Lee SG, Lee U, Noh HS, Lee JH (2016) Several factors affecting seed emergence, seedling quality and 
survival of potted seedling on Ligularia fischeri. J Korean For Soc, 105, 63-72

9. Cho DH, Park CH, Park BJ, Shin SE, Lee KC, Yu CY, Ahn SD (1997) Effects of growth regulators, temperature, and light on the germination in wild vegetable (Chwinamul) seeds. Korean J Plant Res, 10, 39-44

10. Han SS, Jeon SR, Sa JY, Lee GC (2008) Characteristics of physiological responses of Ligularia fischeri, Ligularia stenocephala, Ligularia fischeri (Ledebour) Turczaninow var. spiciformis Nakai leaves. Paper presented at summer academic presentation of Korean Forestry Society, August $21^{\text {st }}$, Jeonbuk, p 249-252

11. Kim GT (2003) A study on the growth, photosynthetic rate and chlorophyll contents of Ligularia fischeri by the growing sites. J Korean For Soc, 92, 4, 374-379

12. Cho MS, Kim GN, Park GS, Lee SW (2010) Physiological responses of Allium victorialis var. platyphyllum, Ligularia fischeri and Ligularia stenocephala growing at different fertilizing schemes. J Bio-environement Control, 19, 97-108

13. Lee HS, Ahn CH, Kim CW, Lee JS (2009) Cultivation of Ligularia fischeri, Ligularia stenocephala, and Allium vitorialis var. platyphyllum in broad-leaved deciduous forest. Paper presented at summer academic presentation of Korean Forestry Society, August 19, Seoul, p 111-113

14. Han SS, Lee KC, Jeon SR (2010) Studies on the agroforestry methods of wild edible greens (IV): Water relations parameters of three Ligularia species leaves obtained from P-V curves. J Korea For Soc, 99, 131-135

15. Moon YG, Kim SW, Choi JK, Kwon SB, Shim HS, Ju HJ, Choi IY (2015) Stem rot on Ligularia fischeri caused by Sclerotium rolfsii in Korea. Res Plant Dis, 21, 36-39

16. Hong CK, Bang SB, Kwon SB, Kim SC, Mo YM (1997) Studies on the nutri-culture of major wild vegetable Ligularia fischeri Turcz.: I. Growth and yield of Ligularia fischeri Turcz. by media, amount of media and planting density in nutri-culture. Korean J plant Res, 10, 401-410

17. Park SB, Kim MJ, Park YM, Hwang SI, Kim EG (2012) Profitability analysis for Ligularia fischeri forest farming. J Korean For Soc, 101, 426-433

18. Bae JH, Yu SO, Kim YM, Chon SU, Kim BW, Heo BG (2009) Physiological activity of methanol extracts from Ligularia fischeri and their hyperplasia inhibition activity of cancer cell. J Bio-Environment Control, 18, 67-73

19. Shang YF, Kim SM, Song DG, Pan CH, Lee WJ, Um $\mathrm{BH}$ (2010) Isolation and identification of antioxidant compounds from Ligularia fischeri. J Food Sci, 75, 530-535

20. Kim SM, Jeon JS, Kang SW, Jung YJ, Ly LN, Um BH (2012) Content of antioxidative caffeoylquinic acid derivatives in field-grown Ligularia fischeri (Ledeb.) Turcz and responses to sunlight. J Agric Food Chem, 60, 5597-5603

21. Kim GN, Cho MS, Kwon KW (2010) Analysis of growth performance and ascorbic acid contents of Allium victorialis var. platyphyllum, Ligularia fischeri, and $L$. stenocephala under changing light intensity. J Korean For Soc, 99, 1, 68-74

22. Choi EM, Ding Y, Nguyen HT, Park SH, Kim YH (2007) Antioxidant activity of Gomchi (Ligularia fischeri) leaves. Food Sci Biotechnol, 16, 710-714

23. Lee CB (2003) An illustrated guide to Korea flora. Hyung MunSa Pubilshing Co Inc, Seoul, Korea, p 910

24. Lee SY (2010) Fermentative characteristics, health functional activity, and quality evaluation of Ligularia fischeri and Spinacia oleracea kimchis. MS Thesis, The Catholic University of Korea, Korea

25. Park BH, Joo HM, Cho HS (2014) Quality characteristics of dried noodles added with Ligularia fischeri powder. Korean J Food Culture, 29, 205-211

26. Kang IJ, Ham SS, Chung CK, Lee SY, Oh DH, Do JJ (1999) Production and characteristics of fermented soy sauce from mountain herbs. Korean J Food Sci Technol, 31, 1203-1210

27. Kang YS, Kim JS (2011) Quality characteristics of Sulgidduk supplemented with Ligularia fischeri powder. J East Asian Soc Dietary Life, 21, 277-283

28. Choi SR (2014) Physicochemical properties of Chwi-namul and quality characteristics of Injeulmi containing different ratio of Chwi-namul (Aster scaber, Ligularia fischeri, Synurus deltoids). Ph D Thesis, Sejong University, Korea

29. Park BH, Kim M, Jeon ER (2013) Quality characteristics of tofu added Ligularia fischeri powder. Korean J Food Culture 28, 495-501

30. Sun YP, Jeong YJ, Han YS (2016) Antioxidative activities and quality characteristics of steamed roll with added Ligularia fischeri (Ledeb.) Turcz. powder. Korean J Food Cook Sci, 32, 147-156

31. AOAC (2000) Official Methods of Analysis. 17th ed, Association of Official Analytical Chemists, Gaithersburg, $\mathrm{MD}$, USA, p 1-26

32. KFDA (2007) Test method in general. Int'l Food code 
(separate volume). Korea food and drug administration, Cheongju, Korea, p 1267

33. Gancedo MC, Luh BS (1986) HPLC analysis of organic acids and sugars in tomato juice. J Food Sci, 51, 571-573

34. Folin O, Denis W (1912) On phosphotungasticphosphomolybdic compounds as color reagents. J Biol Chem, 12, 239-243

35. Moreno MI, Isla MI, Sampietro AR, Vattuone MA (2000) Comparison of the free radical-scavenging activity of propolis from several regions of Argentina. $\mathbf{J}$ Ethnopharmacol, 71, 1, 109-114

36. Choi SH, Lee BH, Choi HD (1992) Analysis of catechin contents in commercial green tea by HPLC. J Korean Soc Food Nutr, 21, 386-389

37. Friedman M, Jurgens HS (2000) Effect of $\mathrm{pH}$ on the stability of plant phenolic compounds. J Agric Food Chem, 48, 2101-2110

38. Ganzon JG, Chen LG, Wang CC (2018) 4-O-Caffeoylquinic acid as an antioxidant marker for mulberry leaves rich in phenolic compounds. J Food Drug Anal, 26, 985-993

39. Hyun KW, Koo KC, Jang JH, Lee JG, Kim MR, Lee JS (2004) Quality characteristics and flavor compounds of Geumsan perilla leaves cultivated in greenhouse and field. Korean J Food Preserv, 11, 28-33

40. Hwang JB, Yang MO, Shin HK (1997) Survey for approximate composition and mineral content of medicinal herbs. Korean J Food Sci Technol, 29, 671-679
41. Lee KC, Noh HS, Kim JW, Ahn SY, Han SS (2012) Changes of characteristics related to photosynthesis in Synurus deltoides under different shading treatments. Korean J Medicinal Crop Sci, 20, 320-330

42. Park HJ, Lee KY (2013) Evaluations on antioxidant effect of methanol extract from immature cotton boll. Korean J Plant Res, 26, 4, 426-432

43. Sun J, Chu YF, Wu X, Liu RH (2002) Antioxidant and antiproliferative activities of common fruits. J Agric Food Chem, 50, 7449-7454

44. Suh JT, Choi EY, Yoo DL, Kim KD, Lee JN, Hong SY, Kim SJ, Nam JH, Han HM, Kim MJ (2015) Comparative study of biological activities at different harvesting times and new varieties for highland culture of Gom-chwi. Korean J Plant Res, 28, 391-399

45. Chon SU (2010) Shading effect on plant growth and physiological activity of Youngia sonchifolia grown in plastic house. Korean J Weed Sci, 30, 215-224

46. Bell AA (1981) Biochemical mechanisms of disease resistance. Ann Rev Plant Physiol, 32, 21-81

47. Xiong LG, Li JA, Li YH, Yuan L, Liu SQ, Huang JA, Liu ZH (2013) Dynamic changes in catechin levels and catechin biosynthesis-related gene expression in albino tea plants (Camellia sinensis L.). Plant Physiol Biochem, 71, 132-143

48. Park HJ (2010) Chemistry and pharmacological action of caffeoylquinic acid derivatives and pharmaceutical utilization of Chwinamul(Korea mountainous vegetable). Arch Pharmacal Res, 33, 1703-1720 